Blackburn, T. H. \& Hobson, P. N. (1960). J. gen. Microbiol. 22, 290-294

\title{
Breakdown of Protein and Proteolytic Activity in the Sheep Rumen at Different Times after Feeding
}

\author{
By T. H. BLACKBURN AND P. N. HOBSON \\ The Rorvett Research Institute, Bucksburn, Aberdeen
}

SUMMARY: In sheep fed on a partially.'defined' diet the dietary protein was broken down in the rumen very rapidly after feeding. In conformity. with this, the proteolytic activity of the rumen micro-organisms was relatively constant and comparatively high even before feeding. The number of proteolytic bacteria which were cultured from the rumen was relatively low at all times, although it increased after feeding.

In the two previous papers (Blackburn \& Hobson, $1960 a, b$ ) the bacterial fractions of rumen contents were shown to possess proteolytic activity, but only a few proteolytic types of bacteria were isolated and these occurred in comparatively small numbers, usually not more than about $10^{7} / \mathrm{ml}$. rumen contents. Appleby (1955) also isolated proteolytic bacteria in about the same numbers from sheep. Since the total number of rumen bacteria is at least $10^{\circ} / \mathrm{ml}$. (see, for instance, Table 1 (Blackburn \& Hobson, 1960 b), and counts by Moir \& Williams (1950) from sheep on diets in which the protein intake varied and up to $80 \%$ was supplied as casein) the proteolytic bacteria isolated accounted for only about $1 \%$ of this total. It seemed from the previous results that not all the proteolytic bacteria were being isolated, but the numbers of such bacteria might also vary during the day. A source of non-protein nitrogen is necessary for the growth of carbohydrate-fermenting rumen bacteria, only a comparatively few of which are proteolytic, and this nitrogen can usually only come from the breakdown of foodstuff protein, suggesting that proteolytic activity must be high even before feeding, or must develop rapidly after this, to ensure the rapid hydrolysis of ingested protein. Since at the time of these experiments there was little data available on the breakdown of food protein and the redistribution of protein nitrogen, or the variation in proteolytic activity and number of proteolytic bacteria during a feeding cycle, it seemed of interest to extend the previous observations to cover these points and to provide further data on which to base the isolation of proteolytic bacteria. In order to be able to determine the redistribution of nitrogen it seemed preferable to feed a partially-'defined' diet in which the protein could be supplied in a known form. To investigate the effect of different forms of protein this was supplied in the diet as casein in a 'soluble', a heat-treated 'insoluble', and a dissolved form. Two sheep were used in the experiments and each diet was fed to both sheep for a period before any measurements were made. The measurements were repeated on each animal to ensure that reproducible results were obtained. Nitrogen balance experiments during the feeding of two of the rations showed that they were adequate and that the 
animals behaved in a normal manner. The results of all the experiments will be reported in detail elsewhere. In this paper the results of counts of the proteolytic bacteria and the measurements of proteolytic activity on the three diets, and the redistribution of nitrogen on the diet containing the 'soluble' casein will be given.

\section{METHODS}

Rations. The sheep were fed at 9 a.m. and 4 p.m. on chopped wheat straw, 300 g.; mix $a, 175$ g.; molasses, 10 g.; damped with water, $600 \mathrm{ml}$., and well mixed. Drinking water was allowed only during the night. Mix $a$ consisted of Glaxo C casein (Glaxo Laboratories Ltd., Greenford, Middlesex), 60 g.; potato starch, 75 g.; sucrose, 25 g.; salts mixture, 15 g.; Adisco vitamin supplement (Isaac Spencer Ltd., Aberdeen), $88 \mathrm{mg}$. The salts mixture was that used by McDonald \& Hall (1957). After an initial period the sheep ate this feed in about $10 \mathrm{~min}$. The other diets were similar, but the casein used was heattreated 'insoluble' casein (Chalmers, Cuthbertson \& Synge, 1954), or the Glaxo casein dissolved as below and added as a solution in place of the water.

Sampling. Samples were taken through a permanent rumen cannula from as many different parts of the rumen as possible, a total of $100 \mathrm{ml}$. being obtained at one sampling. Preliminary experiments showed that reproducible results could be obtained by taking daily samples at a period after feeding which increased by $1 \mathrm{hr}$. each day. Each sample was strained through two layers of gauze to remove the larger debris, mainly straw; this debris was washed once in saline to remove adhering micro-organisms as far as possible. Portions of the first strained liquid, $F_{1}$, were used for viable counts of bacteria, determinations of proteolytic activity and measurement of ammonia. Further portions were mixed with the washings and used for preparations of protozoal and bacterial fractions (by centrifuging at $114 \mathrm{~g}$ and $19,000 \mathrm{~g}$ and washing) and determination of protein nitrogen (precipitated by $0.36 \mathrm{~N}$-trichloracetic acid (TCA)) and non-protein nitrogen.

Viable counts of proteolytic bacteria. Since of the media tested previously (Blackburn \& Hobson, 1960b) that containing rumen fluid appeared to support the most mixed bacterial population a similar medium was used in these experiments. It contained solution $a, 15 \mathrm{ml}$; solution $b, 15 \mathrm{ml}$; Difco yeast extract, 0.1 g.; $2 \%$ (w/v) Eastman casein, $25 \mathrm{ml}$.; rumen fluid, $20 \mathrm{ml}$.; water, $16.4 \mathrm{ml} . ; 0.1 \%(\mathrm{w} / \mathrm{v})$ resazurin, $0.1 \mathrm{ml}$. Rumen fluid was taken from a hay and concentrates fed sheep $3 \mathrm{hr}$. after feeding the hay and $7 \mathrm{hr}$. after feeding concentrates and clarified by centrifuging at $20,000 \mathrm{~g}$. After autoclaving (120 ${ }^{\circ}$, $15 \mathrm{~min}$.) the medium was gassed with sterile oxygen-free $\mathrm{CO}_{2}$ and solution $c, 8.8 \mathrm{ml}$., and filtered glucose solution, $0.25 \mathrm{ml}$. ( $0 \cdot 1 \mathrm{~g}$.) added. The medium was dispensed in $9 \mathrm{ml}$. amounts under $\mathrm{CO}_{2}$. Dilutions of rumen fluid $\mathrm{F}_{1}$ were made, less than $1 \mathrm{hr}$. after sampling, directly in the medium under $\mathrm{CO}_{2}$ and incubated for 4 days at $37^{\circ}$. Solutions $a, b$, and $c$ were described in Blackburn \& Hobson, 1960b. After incubation a sample from each culture was examined by Gram staining, and to a further sample (1 ml.) was added $0.72 \mathrm{~N}$-trichloroacetic acid (TCA), $2 \mathrm{ml}$. The degree of turbidity produced was 
then visually recorded on a scale which was graded as follows: ++++ , clear (i.e. complete proteolysis); +++ , clear with slight opacity; ++ , definite opacity bordering on flocculation; + , flocculation; - , precipitation. An opacity graded ++ was taken as the limiting value for indicating proteolysis. The bacteria which grew were classed into ten morphological types.

Proteolytic activity. Digests were as follows: strained rumen fluid $\mathrm{F}_{1}, 1 \mathrm{ml}$; $2 \%(w / v)$ Eastman casein solution, $5 \mathrm{ml}$; 0.1 M-phosphate buffer (pH 6.6), $3 \mathrm{ml}$; $0.6 \%(\mathrm{w} / \mathrm{v}) L$-cysteine hydrochloride, $1 \mathrm{ml}$. After incubation under toluene at $37^{\circ}$ for $24 \mathrm{hr}$. portions $(1 \mathrm{ml}$.) were removed and the remaining protein precipitated by addition of 0.72 N-TCA, $9 \mathrm{ml}$. The amount of 'tyrosine' in the supernatant was then determined by Folin reagent, after the oxidation procedure mentioned in Blackburn \& Hobson (1960a), and the precipitated casein was dissolved in $0.1 \mathrm{~N}-\mathrm{NaOH}, 2 \mathrm{ml}$, and determined by biuret reagent.

Control digests contained, 1 , water, in place of casein; 2, water in place of rumen fluid.

Reagents. Solutions of Eastman casein (Kodak Ltd., Hemel Hempstead,

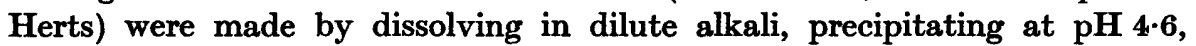
washing, redissolving in dilute alkali and adjusting to pH 6.8 (McDonald \& Gibbons, 1955). The solution was then adjusted to a protein concentration of $2 \%(w / v)$ on a basis of nitrogen $\times 6 \cdot 25$. The solution was kept at $4^{\circ}$ for not longer than 2 weeks, or freeze-dried and redissolved as needed.

\section{RESULTS}

Representative results from one experiment showing the changes in concentration of the different nitrogenous materials in the rumen after feeding the diet containing 'soluble' casein are shown in Fig. 1. Figure 2 shows the proteolytic activity at different times after feeding the three diets, as measured by the 'biuret' method. The activity measured by the Folin reagent method showed similar fluctuations with time. The highest dilutions of rumen contents at which growth of bacteria led to proteolysis in the cultures are also shown in Fig. 2. The results in Fig. 2 are averages from experiments on two sheep, in the case of the soluble casein diet being from three experiments, the insoluble diet two experiments and the dissolved casein diet four experiments.

It is evident that there was a rapid breakdown of soluble or easily attacked foodstuff protein almost immediately after feeding, as shown by the rapid increase in non-protein nitrogen. The maximum amount of non-protein nitrogen extractable from the feed in a buffer resembling saliva in mineral content and $\mathrm{pH}$ was approximately equivalent to $8 \mu \mathrm{g}$. atoms $\mathrm{N} / \mathrm{ml}$. in the rumen. Under the same conditions $27 \cdot 1 \%$ of the food protein was soluble. The breakdown of protein was followed by deamination and formation of ammonia and increase in microbial protein. Moore \& King (1958) found a similar rapid increase and diminution in the soluble non-protein nitrogen in the bovine rumen. The results of the determinations of proteolytic activity show that although there was some increase in activity after feeding, the rapid breakdown of foodstuff protein was due more to there being a relatively constant 


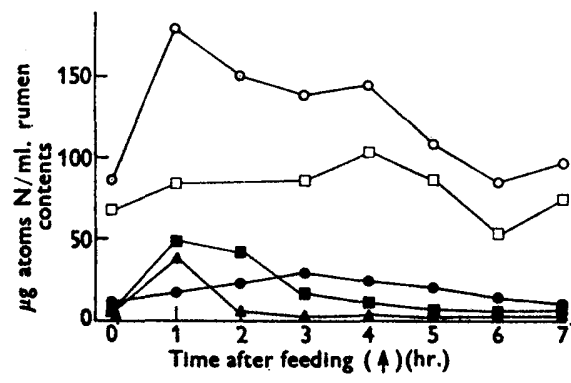

Fig. 1

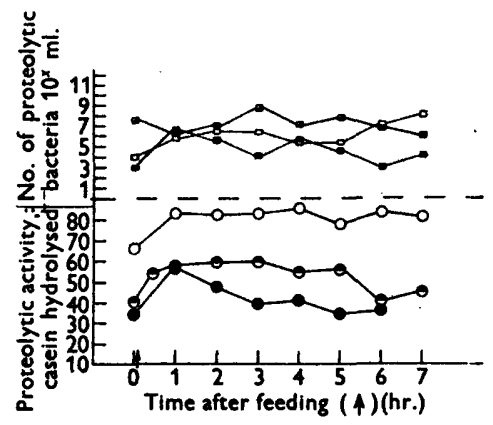

Fig. 2

Fig. 1. Redistribution of nitrogen in the sheep rumen after feeding. Diet: straw, 'soluble' casein, minerals, carbohydrates (see text). Time of feeding 9 a.m. $\uparrow$. Total nitrogen, $O$; soluble protein nitrogen, $\Delta$; non-protein non-ammonia nitrogen, $\mathbf{D}$; ammonia nitrogen, ; protozoal and bacterial nitrogen,

Fig. 2. Proteolytic activity and numbers of proteolytic bacteria in the sheep rumen after feeding. Diet: straw, casein, minerals, carbohydrates (see text). Proteolytic activity, 'soluble' casein diet, $O$; 'insoluble' casein, $\odot$; dissolved casein, $\odot$; counts of proteolytic bacteria (for methods see text); 'soluble' casein diet, $\square$; 'Insoluble' casein, $\square$; dissolved casein, $\square$.

proteolytic activity in the rumen, rather than to a sudden increase in enzyme activity. A fair proportion of this activity was probably due to the protozoa, and the protozoa may be more active in hydrolysis of particulate protein than the bacteria (Blackburn \& Hobson (1960a). An increased contribution from

Table 1. Main types of bacteria growing and highest dilutions showing proteolysis in cultures from a sheep on a diet containing 'soluble' casein

For medium see text.

Types of bacteria. $\mathrm{m}=$ mixed bacteria, no predominant types. $1=\mathrm{G}+$ cocci, $1 \mu$. $2=\mathbf{G}+$ bacillus types. $8=\mathbf{G}+$ small rods in pairs. $4=\mathrm{G}-$ cocci, $0.8-1 \mu .5=\mathrm{G}-$ coccobacilli, $0.6 \mu$. $6=G-$ straight rod, $0.5 \mu$ diameter. $7=G-$ thin curved rod, $0.2-$ $0.4 \mu \times 2 \mu .8=G-$ stout curved rod, $0.6-0.8 \mu \times 8-4 \mu .9=G-$ long thin curved rods in twining chains. $10=G-$ terminal sporing rod.

Type 8 bacteria did not appear in this particular experiment.

$\mathbf{G +}, \mathbf{G}-$ = Gram-positive, Gram-negative.

$-=$ no growth.

\begin{tabular}{|c|c|c|c|c|c|c|c|c|}
\hline \multirow{3}{*}{$\begin{array}{c}\text { Dilution } \\
\text { of } \\
\text { rumen } \\
\text { contents } \\
10^{8}\end{array}$} & \multicolumn{8}{|c|}{ Time after feeding (hr.) } \\
\hline & $\mathbf{0}$ & $\mathbf{I}$ & 2 & \multicolumn{3}{|c|}{${ }_{\text {Bacteria growing }}^{3}$} & 6 & 7 \\
\hline & 4578 & 8 & $\mathbf{m}$ & $8 m$ & $\mathbf{5 1}$ & $\mathbf{5 7 8 1}$ & $\mathbf{5 m}$ & 5781 \\
\hline 104 & 45781 & 8 & $1 \mathbf{m}$ & $8 \mathrm{~m}$ & 51 & 5781 & 578 & 5781 \\
\hline $10^{8}$ & 45781 & 184 & $1 \mathrm{~m}$ & $8 \mathrm{~m}$ & 51 & 5781 & 5781 & 17 \\
\hline $10^{6}$ & 17 & 178 & 185 & 1 & 182 & 5781 & 5781 & 17 \\
\hline $10^{7}$ & 57 & 785 & 9 & 9 & 95 & 5781 & 5781 & 1247 \\
\hline $10^{8}$ & 7 & 92 & 8 & 9 & 8 & 56 & 4 & 2 \\
\hline $10^{\circ}$ & 7 & - & 52 & 2 & 10 & 951 & - & $\boldsymbol{5}$ \\
\hline $10^{10}$ & 15 & - & - & 2 & - & 951 & - & 5 \\
\hline $10^{11}$ & - & - & - & - & - & $\mathbf{2}$ & - & 5 \\
\hline $\begin{array}{l}\text { shest dilution } \\
\text { owing proteol }\end{array}$ & $10^{4}$ & $10^{7}$ & $10^{6}$ & $10^{10}$ & $10^{7}$ & $10^{5}$ & $10^{5}$ & $10^{\circ}$ \\
\hline
\end{tabular}


the protozoa or the large bacteria, which were not cultured, may explain the rather higher proteolytic activity found on the 'soluble' casein diet, as compared with the counts of proteolytic bacteria.

The bacterial population in the rumens of the sheep on the synthetic diets was similar to that of sheep on other concentrate-type diets and the results obtained here could be taken as representative of general rumen function. The medium used for viable counts was designed to culture as many types of rumen bacteria as possible, and in general a mixed population did grow (Table 1; the results of one experiment). The number of proteolytic bacteria present were generally higher on the diet containing dissolved casein, but in all cases the numbers were fairly constant, and comparatively low, suggesting that in previous experiments, although the types of bacteria isolated were limited, they did bear a reasonable relationship to the total numbers of proteolytic small bacteria. However, as mentioned before, some of the proteolysis occurring in the mixed cultures may have been caused by the combined actions of a number of bacteria. From the results of previous experiments, in which it was found that only a proportion of morphologically similar types were proteolytic, it would be expected that no general correlation would be found between the types of bacteria growing and the morphological forms, but the small Gram-positive cocci, and Gram-negative coccobacilli seemed generally to be present, as did the Gram-negative curved rod types.

The authors wish to thank Mr J. McIntosh for technical assistance in all the experiments described in these papers.

\section{REFERENCES}

Appleby, J. C. (1955). The isolation and classification of proteolytic bacteria from the rumen of the sheep. J. gen. Microbiol. 12, 526.

Blackburn, T. H. \& Hobson, P. N. (1960a). Proteolysis in the sheep rumen. by whole and fractionated rumen contents. J. gen. Microbiol. 22, 272.

Blackburn, T. H. \& Hobson, P. N. (1960b). Isolation of proteolytic bacteria from the sheep rumen. J. gen. Microbiol. 22, 282.

Chalmers, M. I., Cuthbertion, D. P. \& Synae, R. L. M. (1954). Duodual administration and heat processing as factors influencing fate of casein supplements. J. agric. Sci. 44, 254.

McDonald, I. J. \& Gibbons, W. E. (1955). Utilisation of sodium caseinate by Lactobacillus casei. Canad. J. Microbiol. $1,365$.

McDonald, I. W. \& HaLl, R. J. (1957). The conversion-' of casein into microbial proteins in the rumen. Biochem. $J .67,400$.

MoIr, R. J. \& Williams, V. J. (1950). The effect of level of nitrogen intake upon the total numbers of free microorganisms in the rumen. Aust. J. Sci. Res. $B, 3,381$.

Moore, W. E. C. \& Knve, K. W. (1958). Determination of the intraruminal distribution of soluble nitrogen. J. Dairy Sci. 41, 1451.

(Received 25 August 1959) 